\title{
The Effect of School Administrators' Political Skills against Organizational Cynicism in Educational Organizations
}

\author{
Tuğba Konaklı \\ Faculty of Education, Kocaeli University, Turkey
}

Copyright $(2016$ by authors, all rights reserved. Authors agree that this article remains permanently open access under the terms of the Creative Commons Attribution License 4.0 International License

\begin{abstract}
In the present study, it is aimed to investigate the relationship between the primary school teachers' perceptions of the political skills of school administrators and their perceptions of organizational cynicism. Within the scope of this general purpose, it was investigated whether there was a significant relationship between teachers' perceptions of school administrators' political skills and cognitive, emotional, and behavioral cynicism. The universe of the study is composed of teachers working in the primary schools within the central district borders of Kocaeli province of Turkey. 350 teachers from 21 primary schools chosen via simple random sampling from among 54 primary schools in İzmit district of Kocaeli province made up the sample of this study. "Organizational Cynicism Scale" developed by Brandes et al. (1999) and Political Skill Inventory (PSI) developed by Ferris, Treadway et al. (2005) was used in the present study. The study findings demonstrate a significant positive relationship between the teachers' perceptions of political skills and organizational cynicism. It was also found out that the sincerity dimension of the school administrators' political skills significantly predicts cognitive, emotional, and behavioral cynicism while the social astuteness and sincerity dimensions together have a significant influence on emotional cynicism.
\end{abstract}

Keywords School Administrator, Political Skill, Educational Organization

\section{Introduction}

Rapidly changing living conditions have necessitated transformation from old models to new ones in the structures of schools. This transformation occurs from hierarchical bureaucratic designs towards more networked and flexible designs in schools. It has also brought along some important changes in and expectations about the roles and skills of school administrators. Many typologies have been developed about the fundamental and primary skills of administrators. For example, Mann [33] developed a three dimensional typology about administrators' skills: executive, interpersonal, and technical abilities. Katz [27] defined the conceptual skill as an important ability in the upper positions of organizations, technical skills in lower ones, and interpersonal skills at the bottom. Mintzberg [35], defined 10 managerial roles; Figurehead, Leadership, Liaison, Monitoring, Disseminator, Spokesman, Entrepreneurship, Disturbance Handler, Resource Allocator, Negotiator and also Lau et al. [32] determined 4 main skill areas about managerial roles: problem-solving skills (similar to the technical skills dimension), observance and supervision (similar to the interpersonal skills dimension), collecting information, and planning and decision-making. Mumford et al. [36] gathered leadership skills under 4 dimensions: cognitive skills, interpersonal skills, professional skills, and strategic skills. It was found out that leadership skills vary by the nature of the job performed and the administrative level. It was also stressed that cognitive skills are necessary on all organizational levels while strategic skills are necessary and important more in the upper positions of an organization.

Indicating that a four-dimensional structure plays a critical role in the success of managers, Scullen et al. [43] used the studies of Mann [33] and Katz [27] as the baseline in their own study. The first of these dimensions is technical skills which are about using special methods in one's own expertise area. Another dimension is managerial skills which are about making effective plans, managing organization, and coordination. The third dimension is interpersonal skills which are about the ability to productively work in a team. As for the fourth dimension (i.e. citizenship behavior), it involves the other aspects of professional behavior such as being loyal, cooperative, and insistent. In the research conducted with managers in an extensive sampling by Tonidandel et al. [46], it was found out that traditional managerial skills are related to managerial efficiency. However, the traditional managerial skills accounted for $15 \%$ of the variance in managerial efficiency. Thus, it was 
asserted that managerial efficiency can be explained better by handling different aspects of managerial skills more comprehensively.

\subsection{Political Skill}

Described differently from the traditional managerial skills in literature, political skill is considered a social astuteness measure. Thus, it is defined as the ability to use the skill of efficiently understanding and impressing the employees in a work place with the purpose of enhancing employees' individual and/or organizational targets [3].

Political skill has 4 dimensions which are (1) social astuteness, (2) interpersonal influence, (3) networking ability, and (4) apparent sincerity [19]. Social astuteness is about observing the employees' behavior and interpreting it successfully. Interpersonal influence is about the manager's seeing the details in cases that cannot be noticed easily by everyone and his/her strong ability to persuade. Networking ability is defined as the ability of entering easily into a new environment, making new friends, and building partnerships in order to achieve individual and organizational goals. Lastly, sincerity dimension refers to perception as honest, sincere, and reliable by employees. The managers with this ability demonstrate effective listening skills [19].

Even though political skill is similar to the interpersonal and citizenship behavior dimensions in the previous typologies, it has certain aspects different from them.
Though interpersonal dimension encompasses such abilities as getting along well with employees, relieving them, and managing conflicts, it does not include the abilities of networking, observing and interpreting employees, and behaving them sincerely which are associated with political skill. As for the citizenship behavior, it can be associated with sincerity skills, but does not encompass the skills within the dimensions of social astuteness, networking ability, and interpersonal influence. It is reported in research that political skills are related to personal characteristics such as self-efficacy [51] extraversion [22] and job-related results [21] such as professional success [48], [6], job satisfaction [18], [6], team performance [3], [6], employees' responses [45], efficiency of the leader [15], and stress factors [34]. It was found that leaders with high political skills have more power to influence employees in line with organizational aims. It is asserted that managers' having political skills is the most important strength in organizational environments where uncertainty, disorder, and disturbance prevail [17]. According to research results, of Braddy and Campbell (2014) leaders mostly prefer apparent sincerity. Also they found that the network ability is the least dimension that leaders prefer to use. Atay [2], figured out the classification of research results about political skill in his research. The classification of concepts related to political skill in organizational level, interpersonal level and individual level in Atays' (2010) research is showed in Figure 1.

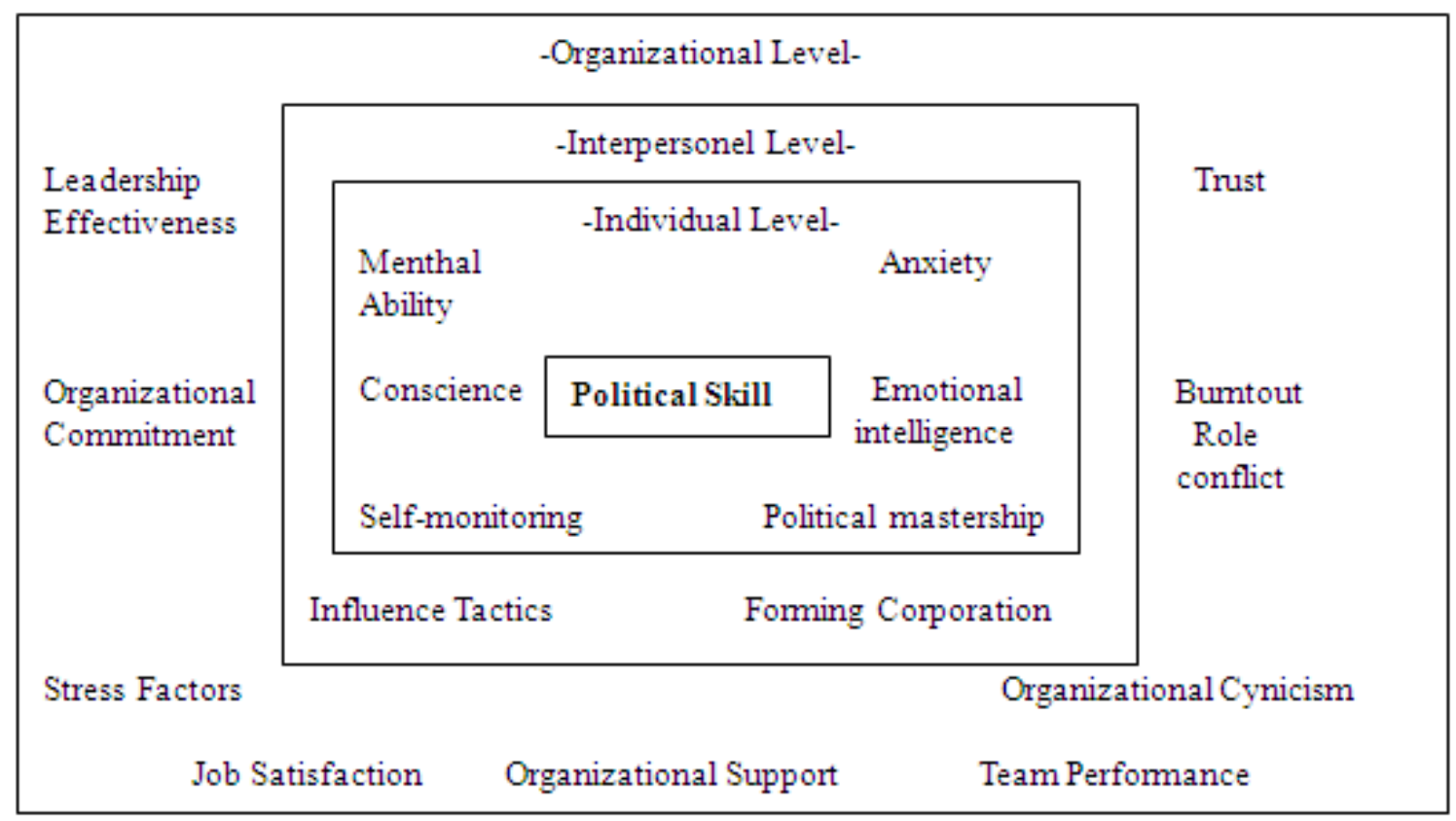

Figure 1. Classification of concepts related to political skill in organizational level, interpersonal level and individual level. 


\subsection{Organizational Cynicism}

The sacrifice of honesty, fairness, and sincerity for the sake of personal interests underlies cynicism [24]. Organizational cynicism is described as the negative attitude shown by employees towards the organization in the case that the organizations' process, procedure, and management are not compatible with the interests of the employees [49], [14]. The negative attitudes of employees' towards the organization they work for are characterized by hopelessness, frustration, and distrust [4], [14].

Researchers have considered organizational cynicism a learnt behavior which is the result of injustice and frustration in organizational cases [14]. Also, the employee's experiences based on frustration lead to the emergence of negative judgements and expectations about future cases , [42] For this reason, organizational cynicism might directly affect the employees' attitude towards the organization.

Organizational cynicism encompasses employees' emotional reactions and behavioral tendencies in an organization [14].. Thus, organizational cynicism can be considered a three-dimensional attitude (cognitive, emotional, and behavioral) developed by the employee towards an organization. The cognitive dimension of organizational cynicism is built on the beliefs that individuals have about the others and thus describes the belief that the organization is deprived of honesty and transparency. It can be said that the individuals displaying a cynical attitude in their organization are deprived of organizational principles and rules, do not care about formal procedures and show inconsistent behaviors which are full of lies or tricks [8], [14]. All these conceptualizations reinforce the idea that cynicism can be understood best through cognitive ways [8]. As for the emotional dimension, it underlines the negative feelings and emotional reactions towards an organization such as disrespect, anger, distress, and shame. It can be said that the feelings of disrespect, contempt, hating the others, arrogance, frustration, and mistrust are associated with this dimension [26]. When it comes to the behavioral dimension, it describes negative tendencies towards an organization. In this dimension, employees may have the tendency to make pessimistic predictions regarding the practices and occasions within the organization. They may show negative attitudes and act in a way to humiliate others [14], [31], [39]. Implicative glances and humiliating and condemning laughter among employees may be the examples of cynic behaviors [9]. The organizational reasons that might lead to the emergence and development of cynicism can be listed as follows: lack of social support and recognition in the organization, not being included in the decision-making process, the unbalanced distribution of power in the organization, and lack of communication [23], [37], [42], poor interaction between the leader and employees [10], [11], [16] violation of the psychological contract [25], [41], and the adoption of organizational policies that include the behaviors serving for their own interests rather than for truth and honesty [16].
Also, such factors as poor communication process, perceptions of managerial insufficiency, limited participation in managerial decisions, role ambiguity, and role conflict might also lead to the weakening of distributive, procedural, and interactional justice perceptions. The perception of injustice points to the breach of the psychological contract [4].

When employees feel that their psychological contract is violated (i.e. when they feel that there is a significant difference between what they expect from their employer and what they actually get) they might get angry with, disappointed about, or indifferent about it. The perception of the employee that his/her psychological contract is violated might set the stage for a host of negative outcomes such as anger, ambition, and revenge which might affect his/her professional life badly [4], [47]. This situation triggers organizational cynicism. The cynicism perceptions of employees have a lot of negative consequences for the organization. Some of these are the decline in organizational commitment, low job satisfaction, and alienation [14], [1], decrease in productivity [13], burnout [25], and resistance to change [44].

\subsection{The Relationship between Political Skills and Organizational Cynicism}

The leadership behavior shown by school administrators might affect the organizational perceptions of teachers and lead to a change in their feelings, thoughts, and attitudes about the organization. In this regard, the quality of the leadership in schools is reflected on teachers' and students' success. To Douglas and Ammeter [15], the power of leaders' political skills is a constituent of effective leadership. Leaders with political skills know when to put forward negative situations and are aware of the approaches which can turn these negative situations into positive ones [16]. Treadway et al. [45] found out that the political skills of leaders are positively correlated with organizational trust and job satisfaction and have an effect on the organizational support while there is a negative relationship between political skill and organizational cynicism. Kolodinsky, Hochwarter and Ferris [28] report that there is a relationship between political skills and job satisfaction and job stress. In this regard, school administrators' having political skills might have a positive effect on the increase of organizational efficiency in educational organizations.

\subsection{Objectives}

In the present study, it is aimed to investigate the relationship between teachers' perceptions of the political skills of school administrators and their perceptions of organizational cynicism. Based on this general aim, the answers of the following questions are sought:

1. Is there a significant relationship between teachers' perceptions of school administrators' political skills and organizational cynicism? 
2. Do teachers' perceptions of school administrators' political skills significantly predict cognitive cynicism?

3. Do teachers' perceptions of school administrators' political skills significantly predict affective cynicism?

4. Do teachers' perceptions of school administrators' political skills significantly predict behavioral cynicism?

\section{Materials and Methods}

Correlational design is used to complete the process of this study. The population is composed of teachers working at primary schools within the İzmit district of Kocaeli. There are 1018 teachers working at primary schools in İzmit. The sample size of the study was determined based on Krejcie and Morgan's [29] table for determining sample size. According to this table recommended sample size for a population of 1000 is 278 . In this research 350 teachers from 21 primary schools chosen via simple random sampling from among 54 primary schools in İzmit made up the research sample.

After the incomplete and incorrectly filled forms were removed, 338 survey forms out of 350 survey forms administered to the participants were included in analyses. $64 \%$ of the participants in the study were female, and $36 \%$ were male.

In order to determine the teachers' cynicism perceptions, the "Organizational Cynicism Scale" developed by Brandes et al. (1999) was used in the study. The Turkish linguistic equivalence and validity of the scale were confirmed by Yetim and Ceylan [50]. The cognitive cynicism dimension of the Turkish version of the Organizational Cynicism Scale consists of 5 items, two of which are as follows "I have seen a very little consistency between what was promised to be done in the future and what was actually done in the school where I work."; "The behavior expected from teachers in the school is different from the behavior that is rewarded." As for the emotional cynicism dimension, there are 4 items, two of which are as follows: "I feel concerned when I think about the school I work in."; "I feel tense when I think about the school I work in." In this study, the Cronbach's alpha internal consistency coefficient for the Organizational Cynicism Scale was found to be .80 . In order to determine the teachers' perceptions of school administrators' political skills, the Political Skill Inventory (PSI) developed by Ferris, Treadway et al. [19] was used. The Turkish linguistic equivalence and validity of PSI were confirmed fulfilled by Atay [5]. In the Turkish version of PSI, the participants were asked to express their opinions on a 5-point Likert-type scale in the following arrangement: "I strongly disagree", "I disagree", I partially agree", "I agree", "I strongly agree". Recent research has provided strong evidence for the PSI construct validity (Ferris, Treadway, et al., 2005; Liu et al., 2007) of political skill. Political skill also is associated with income, hierarchical position, and career satisfaction (Blickle, Schneider, Liu, \& Ferris, 2014, Braddy and Campbell, 2014, Munyon et al. 2015).

In order to carry out the PSI exploratory factor analysis, firstly the fitness of the data for factor analysis was tested through Kaiser-Meyer-Olkin (KMO) coefficient and Barlett's test. In this regard, the Kaiser-Meyer-Olkin (KMO) coefficient was found to be 0.799 while the Barlett's test value was found to be $1662.361(\mathrm{p}<0.001)$. Thus, the data were found to be fit for factor analysis [12]. In order to determine the number of factors under which the items included in the factor analysis fell, the eigenvalues and the explained variance percentages were checked in the first place. EFA results indicate that the items fell under 4 factors having an eigenvalue higher than 1 , and only one factor had high factor loading. The total variance explained by the factors was $59.21 \%$. The EFA results regarding the PSI are presented on Table 1.

Table 1. PSI Exploratory Factor Analysis Results

\begin{tabular}{|c|c|c|c|c|}
\hline & Networking Ability & Social Astuteness & Interpersonal influence & Sincerity \\
\hline M1 & .777 & & & \\
\hline M6 & .723 & & & \\
\hline M11 & .670 & & & \\
\hline M10 & .655 & & & \\
\hline M9 & .643 & & & \\
\hline M15 & .516 & & & \\
\hline M5 & & 912 & & \\
\hline M7 & & 898 & & \\
\hline M16 & & 738 & & \\
\hline M17 & & 691 & & \\
\hline M18 & & 612 & & \\
\hline M2 & & & 812 & \\
\hline M3 & & & 768 & \\
\hline M4 & & & 707 & \\
\hline M12 & & & 674 & \\
\hline M8 & & & & 810 \\
\hline M13 & & & & 625 \\
\hline M114 & & & & 564 \\
\hline
\end{tabular}


EFA results show that the Networking Ability dimension encompassing the establishment of connections with important people and having a wide network of colleagues is made up of 6 items and explains $23.692 \%$ of the total variance. Another factor indicated in the factor analysis is the social astuteness dimension made up of 5 items about school administrators' ability to analyze people and explains $17.445 \%$ of the total variance. As for the interpersonal influence dimension about building effective communication and friendly relationships, it is made up of 4 items and explains $10.216 \%$ of the variance. The sincerity dimension emphasizing sincerity in communication is made up of 3 items and explains $7.859 \%$ of the variance. When the correlations between the PSI dimensions were examined, significant positive relationships were found between them. There were also significant positive medium relationships between social astuteness and interpersonal influence $(\mathrm{r}=.496, \mathrm{p}=0.00)$; networking ability $(\mathrm{r}=.687, \mathrm{p}=0.05)$; and sincerity $(r=.484, p=0.05)$ dimensions. Similarly, there were significant positive medium relationships between interpersonal influence dimension and networking ability $(\mathrm{r}=.640, \mathrm{p}=0.05)$ and sincerity $(\mathrm{r}=.290, \mathrm{p}=0.00)$; and lastly there was a significant positive medium relationship between networking ability and sincerity dimensions $(\mathrm{r}=.491, \mathrm{p}=0.00)$. The Cronbach's alpha value for the PSI administered to the teachers was found to be .79 .

Data Analysis

SPSS 20 was used for analyzing data. Pearson's correlation analysis was carried out in order to determine the relationship between the participants' perceptions of school administrators' political skills and their perceptions of organizational cynicism. Also, multilinear regression analyses were conducted for determining the effect of the dimensions making up the political skill on cognitive, affective, and behavioral cynicism.

\section{Results}

Before the analysis of the research data, the normality of the distribution of the data was tested through Kolmogoro-Smirnov test. The analysis results demonstrated the normal distribution of the data $(p>0.000)$. Pearson's correlation analysis was carried out in order to determine whether there was a significant relationship between the participants' perceptions of school administrators' political skills and their perceptions of organizational cynicism. The correlation matrix between the political skill dimensions and the organizational cynicism dimensions is presented on Table 2.

Table 2 shows that social astuteness has a significant negative low relationship with cognitive cynicism $(r=-.259$; $\mathrm{p}=.000)$, emotional cynicism $(\mathrm{r}=-.299 ; \mathrm{p}=.000)$, and behavioral cynicism $(\mathrm{r}=-.149 ; \mathrm{p}=.000)$; interpersonal influence has a significant negative low relationship with cognitive cynicism ( $\mathrm{r}=-.140 ; \mathrm{p}=.000)$, emotional cynicism $(\mathrm{r}=-.130 ; \mathrm{p}=.000)$, and behavioral cynicism $(\mathrm{r}=-.129$; $\mathrm{p}=.000$ ); networking ability has a significant negative low relationship with cognitive cynicism $(r=.247 ; \mathrm{p}=.000)$, emotional cynicism $(\mathrm{r}=-.211 ; \mathrm{p}=.000)$, and behavioral cynicism $(r=-.184 ; \mathrm{p}=.000)$; sincerity has a significant negative low relationship with cognitive cynicism $(r=-.376$; $\mathrm{p}=.000)$, emotional cynicism $(\mathrm{r}=-.325 ; \mathrm{p}=.000)$, and behavioral cynicism $(\mathrm{r}=-.325 ; \mathrm{p}=.000)$. The scatter diagram was examined in order to test the linearity of the relationships of social astuteness, interpersonal influence, networking ability, and sincerity with cognitive, emotional, and behavioral cynicism. The scatter diagram indicated a linear relationship between the variables.

Table 2. The correlation matrix between the political skill dimensions and the organizational cynicism dimensions

\begin{tabular}{|c|c|c|c|c|c|c|c|c|}
\hline & & $\begin{array}{c}\text { Social } \\
\text { astuteness }\end{array}$ & $\begin{array}{c}\text { Interpersonal } \\
\text { influence }\end{array}$ & $\begin{array}{c}\text { Networking } \\
\text { ability }\end{array}$ & $\begin{array}{l}\text { Apparent } \\
\text { sincerity }\end{array}$ & Cognitive & Emotional & Behavioral \\
\hline \multirow[t]{2}{*}{$\begin{array}{c}\text { Social } \\
\text { astuteness }\end{array}$} & $\mathrm{r}$ & 1 & & & & & & \\
\hline & $\mathrm{p}$ & & & & & & & \\
\hline \multirow[t]{2}{*}{$\begin{array}{l}\text { Interpersonal } \\
\text { influence }\end{array}$} & $\mathrm{r}$ & $.496(* *)$ & 1 & & & & & \\
\hline & $\mathrm{p}$ & .000 & & & & & & \\
\hline \multirow[t]{2}{*}{$\begin{array}{l}\text { Networking } \\
\text { ability }\end{array}$} & $\mathrm{r}$ & $.657(* *)$ & $.640(* *)$ & 1 & & & & \\
\hline & $\mathrm{p}$ & .000 & 000 & & & & & \\
\hline \multirow[t]{2}{*}{$\begin{array}{l}\text { Apparent } \\
\text { sincerity }\end{array}$} & $\mathrm{r}$ & $484(* *)$ & $.290(* *)$ & $491(* *)$ & 1 & & & \\
\hline & $\mathrm{p}$ & 000 & .000 & 000 & .000 & & & \\
\hline \multirow[t]{2}{*}{ Cognitive } & $\mathrm{r}$ & $-.259(* *)$ & $-.140(* *)$ & $-.247(* *)$ & $-.376(* *)$ & 1 & & \\
\hline & $\mathrm{p}$ & 000 & .000 & .000 & .000 & .000 & & \\
\hline \multirow[t]{2}{*}{ Emotional } & $\mathrm{r}$ & $-.299(* *)$ & $-.130(* *)$ & $-.211(* *)$ & $-.325(* *)$ & $.269(* *)$ & 1 & \\
\hline & $\mathrm{p}$ & 000 & .000 & .000 & .000 & .000 & .000 & \\
\hline \multirow[t]{2}{*}{ Behavioral } & & $-.149(* *)$ & $-.129(* *)$ & $-.184(* *)$ & $-.253(* *)$ & $.258(* *)$ & $.266(* *)$ & 1 \\
\hline & & 000 & .000 & .000 & .000 & .000 & .000 & .000 \\
\hline
\end{tabular}

$* * \mathrm{p}<0.01 * \mathrm{p}<0.05$ 
Later, a multilinear regression analysis was carried out regarding the effects of social astuteness, interpersonal influence, networking ability, and sincerity dimensions on cognitive cynicism. The analysis results are presented on Table 3. The multilinear regression analysis carried out in order to determine the effects of social astuteness, interpersonal influence, networking ability, and sincerity on the cognitive cynicism dimension of organizational cynicism indicated a significant relationship $(\mathrm{R}=.388$, $\mathrm{R}^{2}=.150$ ) between social astuteness, interpersonal influence, networking ability, and sincerity dimensions and cognitive cynicism $(\mathrm{F}(4.333)=10.626, \mathrm{p}<0.01)$.

The four dimensions together explain $15 \%$ of the total variance in cognitive cynicism. The standardized regression coefficients indicate that the predictor variables' relative order of importance for cognitive cynicism is as follows: sincerity $(\beta=-.317)$, social astuteness $(\beta=-.084)$, networking ability $(\beta=-.055)$, and interpersonal influence $(\beta=-.028)$.

Table 3. Multilinear regression analysis results regarding the political skill dimensions' prediction of cognitive cynicism

\begin{tabular}{ccccc}
\hline Dimensions & $\mathrm{B}$ & $\beta$ & $\mathrm{t}$ & $\mathrm{p}$ \\
\hline Constant & 4.292 & & 20.353 & $.000^{* *}$ \\
$\begin{array}{c}\text { Social astuteness } \\
\text { Interpersonal } \\
\text { influence } \\
\text { Networking } \\
\text { ability }\end{array}$ & -.071 & -.084 & -1.019 & .309 \\
$\begin{array}{c}\text { Apparent } \\
\text { sincerity }\end{array}$ & -.023 & -.028 & -.362 & .718 \\
$\mathrm{R}=.388$ & -.195 & -.317 & -4.483 & $.000 * *$ \\
$\mathrm{~F}(4.333)=$ & $\mathrm{R}=.150$ & & & \\
10.626 & $\mathrm{p}=.000 * *$ & & & \\
$* * \mathrm{p}<0.01 *$ & $\mathrm{p}<0.05$ & & & \\
\hline
\end{tabular}

The significance tests of regression coefficients demonstrate that among predictor variables, only sincerity $(p<0.01)$ is a significant predictor of cognitive cynicism.

A multilinear regression analysis was conducted to see the effects of social astuteness, interpersonal influence, networking ability, and sincerity on emotional cynicism. The analysis results are presented on Table 4.

Table 4. Multilinear regression analysis results regarding the political skill dimensions' prediction of emotional cynicism

\begin{tabular}{ccccc}
\hline Dimensions & $\mathrm{B}$ & $\beta$ & $\mathrm{t}$ & $\mathrm{p}$ \\
\hline Constant & 4.558 & & 20.572 & $.000^{* *}$ \\
$\begin{array}{c}\text { Social astuteness } \\
\text { Interpersonal } \\
\text { influence }\end{array}$ & -.190 & -.216 & -2.595 & $.010^{*}$ \\
$\begin{array}{c}\text { Networking } \\
\text { ability }\end{array}$ & -.022 & -.027 & -.337 & .737 \\
$\begin{array}{c}\text { Apparent } \\
\text { sincerity }\end{array}$ & -.157 & -.245 & -3.438 & $.001^{* *}$ \\
$\mathrm{R}=.366$ & $\mathrm{R}^{2}=.134$ & & & \\
$\mathrm{~F}(4.333)=9.258$ & $\mathrm{p}=.000$ & & & \\
$* * \mathrm{p}<0.01 \quad * \mathrm{p}<0.05$ & & & & \\
\hline
\end{tabular}

The multilinear regression analysis carried out in order to demonstrate the effects of social astuteness, interpersonal influence, networking ability, and sincerity on emotional cynicism dimension of organizational cynicism indicated a significant relationship $\left(\mathrm{R}=.366, \mathrm{R}^{2}=.134\right)$ between social astuteness, interpersonal influence, networking ability, and sincerity and emotional cynicism (F (4.333)= $9.258, \mathrm{p}<0.01)$. The four dimensions together explain $13 \%$ of the total variance in emotional cynicism.

The standardized regression coefficients indicate that the predictor variables' relative order of importance for emotional cynicism is as follows: sincerity $(\beta=-.245)$, social astuteness $(\beta=-.216)$, networking ability $(\beta=-.034)$, and interpersonal influence $(\beta=-.027)$. The significance tests of regression coefficients show that among the predictor variables only sincerity $(p<0.01)$ and social astuteness are significant predictors of cognitive cynicism. A multilinear regression analysis was conducted to see the effects of political skill dimensions on behavioral cynicism. The analysis results are presented on Table 5 .

Table 5. Multilinear regression analysis results regarding the political skill dimensions' prediction of behavioral cynicism

\begin{tabular}{ccccc}
\hline Dimensions & $\mathrm{B}$ & $\beta$ & $\mathrm{t}$ & $\mathrm{p}$ \\
\hline Constant & 4.247 & & 15.901 & $.000^{* *}$ \\
Social astuteness & .017 & .016 & .191 & .849 \\
Interpersonal & -.029 & -.030 & -.370 & .712 \\
$\quad$ influence & -.071 & -.067 & -.686 & .493 \\
Networking ability & -.062 & -.219 & -2.948 & $.004^{* *}$ \\
Apparent sincerity & -.162 & & \\
$\mathrm{R}=.263$ & $\mathrm{R}^{2}=.069$ & & & \\
$\mathrm{~F}(4.333)=4.450$ & $\mathrm{p}=.000$ & & & \\
\hline
\end{tabular}

** $\mathrm{p}<0.01 \quad * \mathrm{p}<0.05$

The multilinear regression analysis carried out in order to determine the effects of social astuteness, interpersonal influence, networking ability, and sincerity on the behavioral cynicism dimension of organizational cynicism indicated a significant relationship $\left(\mathrm{R}=.263, \mathrm{R}^{2}=.069\right)$ between social astuteness, interpersonal influence, networking ability, and sincerity and behavioral cynicism $(\mathrm{F}(4.333)=4.450, \mathrm{p}<0.01)$. The four dimensions together explain $6 \%$ of the total variance in emotional cynicism. The standardized regression coefficients indicate that the predictor variables' relative order of importance for behavioral cynicism is as follows: sincerity $(\beta=-.219)$, social astuteness $(\beta=-.057)$, networking ability $(\beta=-.030)$, interpersonal influence $(\beta=-.016)$. The significance tests of regression coefficients demonstrate that among the predictor variables only sincerity $(\mathrm{p}<0.01)$ is a significant predictor of behavioral cynicism.

\section{Discussion}

Political skills are a set of skills that organization members need to be aware of and develop by accomplishing the goals in today's complex world and using the power ethically in 
order to impress the organization and the organization members [30]. This set of skills is based on the ability of managers and employees to masterfully manage their personal relations with their colleagues, other employees, customers, and their superiors [40]. Thus, the political skills of administrators in educational organizations are meaningful and important as they show how administrators ensure the cooperation and support among employees, how they motivate and encourage the employees to make an extra effort, and whether or not the strategies and policies in the organization are applied successfully.

The findings of the present study demonstrate a significant negative relationship between political skill and organizational cynicism. As a matter of fact, the effects of political skills on team performance [3], leader efficiency [15], stress factors [34] and professional outputs were examined in previous studies, and significant results were obtained in such studies. In addition, there are studies showing that organizational cynicism has a negative relationship with citizenship behavior and organizational commitment while its relationship with alienation is positive [1], [4]. Besides this, it is asserted by Treadway et al. [45] that political leadership skills have an effect on the perceived organizational support, which increases the job satisfaction and organizational trust of employees and decreases organizational cynicism. In consideration of the foregoing, it can be said that the organizational loyalty of employees' is much higher in the organizations having a leader with advanced political skills. The findings also demonstrate that political skills are influential on employees' reactions.

The study findings indicate that the sincerity dimension of political skills has a significant relationship with emotional and behavioral cynicism, and there is a significant relationship between social astuteness and sincerity dimensions and emotional cynicism. Thus, administrators' attitudes regarding listening to their employees' effectively, being sincere to them, and being sensitive about them have an effect on organizational cynicism. The study finding demonstrating that sincerity and social astuteness (i.e. the ability to perceive the underlying intentions behind employees' behaviors and to know people well) have an effect on emotional cynicism shows the importance of employees' feeling that they are understood by their managers. Considering that emotional cynicism triggers the feelings of anger, uneasiness, and shame and reduces the organizational trust, it can be asserted that emotional cynicism may decrease when employees feel that their manager understands them, allocates time to listen to them, and behaves sincerely in this process.

\section{Conclusions}

The present study investigated the relationship between the primary school teachers' perceptions of the political skills of school administrators and their perceptions of organizational cynicism. The study results demonstrate a significant positive relationship between the teachers' perceptions of political skills and organizational cynicism. The results also show that sincerity, which is one of the political skills of administrators, significantly predicts the cognitive, emotional, and behavioral cynicism while social astuteness and sincerity together have a significant effect on emotional cynicism.

When the negative relationship between political skills and cynicism perception, and political skills' power of predicting cynicism are considered, it can be asserted that the steps taken for strengthening the political skills of administrators in educational institutions will mitigate the employees' organizational cynicism perceptions. Ferris et al., [20],[21],[22] stress that political skills are improvable abilities. In this regard, the political skills of school administrators may be supported through trainings for developing political skills. The arrangement of such trainings and their effects on the organizational environment may be focused on in future studies.

The limitation of the present study is that it deals with the analysis of the effect of political skills only on organizational cynicism. The relationship between managers' political skills and job satisfaction, team performance, and organizational commitment may be investigated. Furthermore, the relationship between political skills and cultural values may be investigated in future studies as the existing cultural values might have an effect on managerial practices.

\section{REFERENCES}

[1] Abraham R 2000. Organizational cynicism: bases and consequences. Genetic, Social, and General Psychology Monographs, 126 (3): 269-292.

[2] Atay S. 2010. Improvable Managerial Skill: 'Political Skill' with its Theoretical and Empirical Aspects. TODAĐE's Review of Public Administration, 4 (2): 75-92.

[3] Ahearn KK, Ferris GR, Hochwarter WA, Douglas C, Ammeter AP 2004. Leader political skill and team performance. Journal of Management, 30: 309-327.

[4] Anderson LM, Bateman TS 1997. Cynicism in the workplace: some causes and effects. Journal of Organizational Behavior, 18: 449-469.

[5] Atay, S. 2009. Test of Political Skilen Inventory in Turkey. 17 th National Managament and Organization Congress, May 21-23, 891-896, Eskişehir.

[6] Bedi, Akanksha; Skowronski, Mark 2014. Political skill at work: good or bad? ; understanding its predictors and consequences. SAM Advanced Management Journal, 79(2): $39-47$.

[7] Blickle G, Meurs JA, Wihler A, Ewen C, Peiseler C 2014. Leader inquisitiveness, political skill, and follower attributions of leader charisma and effectiveness: Test of a moderated mediation model. International Journal of Selection and Assessment, 29: 582-599. 
[8] Brandes P, Dharwadkar R, Dean JW 1999. Does organizational cynicism matter? employee and supervisor perspectives on work outcomes. Eastern Academy of Management Proceedings, 150-153.

[9] Brandes P, Das D 2006. Locating behavioural cynicism at work: construct 1ssues and performance implications, employee health, coping and methodologies. Pamela L Perrewe and Daniel C Ganster (Eds.). JAI Press, New York, pp. 233-266.

[10] Bommer WH, Rich G, Rubin R 2005. Changing attitudes about change: Longitudinal effects of transformational leader behavior on employee cynicism about organizational change. Journal of Organizational Behavior, 26: 733-753.

[11] Cole MS, Brunch H, Vogel B 2006. Emotion as mediators of the relations between perceived supervision support and psychological hardiness on employee cynicism. Journal of Organizational Behavior, 27: 463-484.

[12] Çokluk Ö, Şekercioğlu G, Büyüköztürk Ş 2010. Sosyal bilimler için çok değişkenli istatistik: SPSS ve Lisrel uygulamalı. Ankara: Pegem Yayınları.

[13] Chiaburu D S, Peng AC, Oh In-Sue, Banks GC, Lomeli LC 2013. Antecedents and consequences of employee organizational cynicism: A meta-analysis. Journal of Vocational Behavior, 83: 181-197.

[14] Dean JW, Brandes P, Dharwadkar R 1998. Organizational cynicism. Academy of Management Review, 23,341-352.

[15] Douglas C, Ammeter AP 2004. An examination of leader political skill and its effect on ratings of leader effectiveness. The Leadership Quarterly, 15: 537-550.

[16] Davis WD, Gardner WL 2004. Perceptions of politics and organizational cynicism: An attributional and leader-member exchange perspective. Leadership Quarterly, 15, 439-465.

[17] Eran V 2000. Organizational Politics, Job Attitudes, and Work Outcomes: Exploration and Implications for the Public Sector. Journal of Vocational Behavior, 57(3):326-347.

[18] Ewen C, Wihler A, Blickle G, Oerder K, Ellen BP, Douglas C, Ferris GR 2013. Further specification of the leader political skill leadership effectiveness relationships: Transformational and transactional leader behavior as mediators, The Leadership Quarterly, 24: 516-533.

[19] Ferris GR, Treadway DC, Kolodinsky RW, Hochwarter WA, Kacmar CJ, Douglas C, Frink D D 2005. Development and validation of the political skill inventory. Journal of Management, 31: 126-152.

[20] Ferris GR, Davidson SL, Perrewé PL 2005. Political skill at work: Impact on work effectiveness. PaloAlto, CA: Davies-Black.

[21] Ferris GR, Treadway DC, Perrewé PL, Brouer RL, Douglas C, Lux S 2007. Political skill in organizations. Journal of Management, 33,290-320.

[22] Ferris GR, Rogers L, Blass F, Hochwarter W 2009. Interaction of job-limiting pain and political skill on job satisfaction and organizational citizenship behavior. Journal of Managerial Psychology, 24: 584-608.

[23] Fleming P 2005. Workers playtime? boundaries and cynicism in a "culture of fun" program. The Journal of Applied Behavioral Science, 41(1): 285-303.
[24] James, M.S.L. (2005). Antecedents And Consequences Of Cynicism In OrganÔzatÕons: An ExamÕnation of The Potential PosÕtÕve and NegatÕve Effects On School Systems (Dissertation), The Florida State University.

[25] Johnson JL, O'Leary-Kelly AM 2003. The effects of psychological contract breach and organizational cynicism: not all social exchange violations are created equal, Journal of Organizational Behavior, 24(5): 627-647.

[26] Kalağan G 2009. Araştırma Görevlilerinin Örgütsel Destek Algıları ile Örgütsel Sinizm Tutmları Arasındaki İlişki, MA Thesis, Unpublished. Antalya. Akdeniz University, Social Sciences Institute.

[27] Katz RL 1974. The skills of an effective administrator. Harvard Business Review, 9-10: 90-102.

[28] Kolodinsky RW, Hochwarter WA, Ferris GR 2004. Nonlinearity in the relationship between political skill and work outcomes: Convergent evidence from three studies. Journal of Vocational Behavior, 65: 294-308.

[29] Krejcie RV, Morgan DW, 1970. Determining sample size for research activities. Educational and Psychological Measurement. 30: 607-610.

[30] Kurchner-Hawkins R, Miller R 2006. Organizational politics: Building positive political strategies in turbulent times. In E Vigoda-Gadot, A Drory (Eds.). Handbook of Organizational Politics. Cheltenham: Edward Elgar, pp. $328-352$.

[31] Kutanis Rana Ö, Çetinel E 2009. Adaletsizlik algısı sinizmi etkiler mi? Bir örnek olay. 17. Yönetim ve Organizasyon Kongresi Kongre Kitab1, In Osmangazi Üniversitesi, Eskişehir, May 21 to 23, 2009. pp. 693-699.

[32] Lau AW, Newman AR, Broedling LA 1980. The nature of managerial work in the public sector. Public Management Forum, 19: 513-521.

[33] Mann FC 1965. Toward an understanding of the leadership role in formal organization", In: Dubin R, Homans GC, Mann FC, Miller DC (Eds.). Leadership and Productivity, San Francisco: Chandler Publishing, pp. 68-103.

[34] Meurs James A 2008. The Dispositional and Learned Behavior Prediction of Political Skill Dimensions and How Political Skill Affects the Stress Process. Electronic Theses, Treatises and Dissertations. From $<\mathrm{http} / /$ diginole.lib.fsu.edu /etd/2460> Retrieved April 27, 2015.

[35] Mintzberg H 1983. Structure in Fives: Designing Effective Organizations. New Jersey: Prentice-Hall.

[36] Mumford TV, Campion MA, Morgeson FP 2007. Te leadership skills strataplex: Leadership skill requirements across organizational levels. Leadership Quarterly, 18:154-166.

[37] O’Brien K, Leichenko R, Kelkar U, Venema H, Aandahl G, Tompkins H, Javed A, Bhadwal S, Barg S, Nygaard L, West J 2004. Mapping vulnerability to multiple stressors: climate change and globalization in India. Global Environmental Change, 14: 303-313.

[38] Ömer Faruk İ 2005. Siyasal arena metaforu olarak örgütler ve örgütsel siyasetin örgütsel adalet algısına etkisi, Ankara Üniversitesi SBF Dergisi, 60(1): 150-170. 
[39] Özgan H, Çetgin B, Külekçi E 2012. İlköğretim kademesinde görev yapan öğretmenlerin örgütsel sinizm düzeyinin bazı değişkenler açısından incelenmesi. Sosyal Bilimler Araştırma Dergisi, 17:69 - 84 .

[40] Peled A 2000. Politicking for success: The missing skill. Leadership and Organization Development Journal, 21:20-29.

[41] Pugh SD, Skarlicki DP, Passell BS 2003. After the fall: layoff victims trust and cynicism in re-employment. Journal of Occupational and Organizational Psychology, 762: 201-212.

[42] Reichers AE, Wanous JP, Austin JT 1997. Understanding and managing cynicism about organizational change. Academy of Management Executive, 11: 48-59.

[43] Scullen, S.E., Mount, M.K. and Judge, T.A. (2003), "Evidence of the construct validity of developmental ratings of managerial performance", Journal of Applied Psychology, Vol. 88 No. 1, pp. 50-66.

[44] Stanley DJ, Meyer JP, Toplnytsky L 2005. Employee cynicism and resistance to organizational change. Journal of Business and Psychology, 19: 429-459.

[45] Treadway DC, Hochwarter WA, Ferris GR, Kacmar CJ, Douglas C, Ammeter AP, Buckley, MR 2004. Leader political skill and employee reactions. The Leadership Quarterly, 15: 493-513.
[46] Tonidandel S, LeBreton JM, Johnson JW 2009. Determining the statistical significance of relative weights. Psychological Methods, 14(4): 387 - 99.

[47] International Journal of Business and Social Science Vol. 4 No. 12 [Special Issue - September 2013] 304 The Effects of Psychological Contract Breach on Employee Work Behaviors in the Airline Industry: Employee Cynicism as Mediator Kuang-Man, Wan).

[48] Wei LQ, Chiang F, Wu LZ 2012. Developing and utilizing network resources: The roles of political skill. Journal of Management Studies, 381-402.

[49] Wilkerson, J. M. 2002. Organizational cynicism and its impact on human resources management. In: GR Ferris, MR Buckley, DB Fedor (Eds.). Human Resources Management: Perspectives, Context, Functions, and Outcome. Upper Saddle River, NJ: Prentice Hall. pp. 532-546.

[50] Yetim, Serap Akduman, Özden Ölmez Ceylan. (2011). Örgütsel Sinizm ve Örgütsel Vatandaşlık Davranışları Arasındaki İlişkiyi Belirlemeye İlişkin Bir Araştırm. Ejournal of New World Sciences Academy, 6 (1), 682-696.

[51] Zellars KL, Perrew'e PL, Rossi AM, Tepper BJ, Ferris GR. 2008. Moderating effects of political skill, perceived control, and self-efficacy on the relationship between negative affectivity and physiological strain. Journal of Organizational Behavior, 29: 549-571. 